\title{
PEMANFAATAN BIODIESEL DARI MINYAK JELANTAH MENGGUNAKAN GELOMBANG MIKRO
}

\author{
Indah Pratiwi.S.ST., M.T. \\ Corresponding Author E-mail: indahpratiwikimia@gmail.com
}

\begin{abstract}
Increasing fuel demand has an impact for decreasing fossil energy reserves. One of the government ways to solve this problem is by increasing the production of biomass fuels, for example biodiesel. Biodiesel can be produced from waste cooking oil through the transesterification stage that reacts oil molecules with alcohol and catalyst to produce methyl esters. Heating method that can be used is microwaves method. This method utilizes wave emission which is absorbed by the sample to make sample's temperature being higher than surface's temperature of the reactor's wall. In the process of making biodiesel, there are several factors that affected heating process. There are ratio of waste cooking oil and methanol, an amount of catalyst, reaction temperature, voltage, and distance of electrodes. The effect of that factors can be seen from the result of the biodiesel's rendement. From this research, we had ratio 5:1 of waste cooking oil and methanol got $85, \%$ rendement, $2 \%$ of catalyst got $87.12 \%$ rendement, $60{ }^{\circ} \mathrm{C}$ reaction temperature got $88.88 \%$ rendement, $10 \mathrm{kV}$ got $89.12 \%$ rendement, and $1 \mathrm{~cm}$ of electrode's distance got $86.34 \%$ rendement.
\end{abstract}

Keywords: Mining Method, Rainwater, Pumping

Abstrak: Peningkatan kebutuhan bahan bakar minyak berdampak pada penurunan cadangan energi fosil. Salah satu cara pemerintah untuk mengatasi masalah ini adalah dengan meningkatkan produksi bahan bakar biomassa, contohnya biodiesel. Biodiesel dapat diproduksi dari minyak jelantah dengan melalui tahap transesterifikasi yang mereaksikan molekul minyak dengan alkohol dan katalis sehingga didapat metil ester. Metode pemanasan yang dapat digunakan adalah gelombang mikro. Metode ini memanfaatkan pancaran gelombang yang diserap oleh sampel untuk sehingga temperatur sampel lebih tinggi dibandingkan dengan temperatur permukaan dinding reaktor. Dalam proses pembuatan biodiesel terdapat beberapa faktor yang mempengaruhi proses pemanasan yang terjadi yaitu rasio minyak jelantah dan methanol, jumlah katalis, temperatur reaksi, tegangan listrik, serta jarak antar elektroda. Pengaruh dari berbagai faktor tersebut dapat dilihat dari hasil persen rendemen biodiesel yang didapat. Dari hasil penelitian, didapatkan rasio minyak jelantah dan methanol 5:1 menghasilkan persen rendemen sebesar 85.91, jumlah katalis $\mathrm{CaO} 2 \%$, menghasilkan persen rendemen sebesar 87.12 , temperatur reaksi $60^{\circ} \mathrm{C}$ menghasilkan persen rendemen sebesar 88.88, tegangan $10 \mathrm{kV}$ menghasilkan persen rendemen sebesar 89.12, dan jarak elektroda $1 \mathrm{~cm}$ menghasilkan persen rendemen sebesar 86.34.

Kata Kunci : Biodiesel, minyak jelantah, gelombang mikro.

\section{PENDAHULUAN}

Peningkatan kebutuhan bahan bakar minyak (BBM) berdampak pada penurunan cadangan energi fosil. Dalam rangka mengatasi permasalahan tersebut, pemerintah memanfaatkan energi dalam negeri dengan meningkatkan produksi bahan bakar biomassa. Pemanfaatan bahan biomassa sebagai bahan bakar menjadi salah satu solusi yang berpotensi untuk diaplikasikan. Menurut Sugiyono, dkk. (2016), sumber daya biomassa di Indonesia sebesar 32.654 MW sedangkan kapasitas yang terpasang saat ini hanya sekitar 92,726 MW. Melihat kondisi tersebut, maka dilakukanlah suatu penelitian untuk memanfaatkan dan mengembangkan sumber daya biomassa menjadi bahan bakar dengan mengolah biomassa menjadi biodiesel. Salah satu sumber bahan baku biodiesel yang sering digunakan adalah minyak jelantah. Minyak jelantah dapat dikonversi menjadi biodiesel dengan melalui tahap transesterifikasi yang mereaksikan molekul minyak dengan alkohol dan katalis sehingga didapat metil ester. Untuk mengkonversi molekul minyak tersebut menjadi biodiesel diperlukan metode yang dapat mengkonversi minyak dalam jumlah yang tinggi. Metode yang sering digunakan untuk mengkonversi minyak menjadi biodiesel yaitu metode konvensional. Namun sayangnya, penggunaan metode ini kurang efisien karena pemanasannya sangat lambat 
akibat dari transfer energi ke bahan yang bergantung pada arus konveksi dan konduktivitas termal campuran reaksi (Refaat dan Sheltawy, 2008).

Dari kelemahan di atas, penulis melakukan penelitian rancang bangun alat pembuatan biodiesel dengan pemanfaatan gelombang mikro dan memanfaatkan tegangan tinggi untuk proses pemisahan biodiesel dan gliserol. Pada penelitian ini digunakan bahan baku berupa minyak jelantah yang ditinjau dari temperatur reaksi yang digunakan terhadap hasil biodiesel yang didapat agar diperoleh kondisi optimum dan menghasilkan biodiesel dengan kualitas yang memenuhi standar yang berlaku.

\section{TEORI DASAR}

Biodiesel merupakan salah satu alternatif bahan bakar minyak yang dapat diperoleh dari lemak tumbuhan dan hewan (Riviani, dkk., 2011). Biodiesel merupakan monoalkil ester dari asam-asam lemak rantai panjang yang terkandung dalam minyak nabati atau lemak hewani untuk digunakan sebagai bahan bakar mesin diesel.

Reaksi transesterifikasi secara umum merupakan reaksi alkohol dengan trigliserida yang menghasilkan metil ester dan gliserol dengan bantuan katalis basa. Reaksi ini cenderung lebih cepat membentuk metil ester daripada reaksi esterifikasi yang menggunakan katalis asam. Namun, bahan baku yang akan digunakan pada reaksi transesterifikasi harus memiliki asam lemak bebas yang kecil $(<5 \%)$ untuk menghindari pembentukan sabun.

Faktor utama yang mempengaruhi rendemen ester yang dihasilkan pada reaksi transesterifikasi adalah: alkohol

1. Rasio molar antara trigliserida dan

Agar reaksi dapat bergeser ke arah produk, alkohol yang ditambahkan harus berlebih dari kebutuhan stoikiometrinya. Peningkatan alkohol terhadap trigliserida akan meningkatkan konversi tetapi menyulitkan pemisahan gliserol.

2. Jenis katalis yang digunakan
Penggunaan katalisator berguna untuk menurunkan tenaga aktivasi sehingga reaksi berjalan dengan mudah. Bila tenaga aktivasi kecil maka harga konstanta kecepatan reaksi bertambah besar.

\section{Temperatur reaksi}

Transesterifikasi dapat dilakukan pada berbagai temperatur, tergantung dari jenis trigliserida yang digunakan. Jika temperatur semakin tinggi, laju reaksi akan semakin cepat. Temperatur selama reaksi transesterifikasi dapat dilakukan pada rentang temperatur $30-65^{\circ} \mathrm{C}$. Dalam proses transeterifikasi, perubahan temperatur reaksi menyebabkan gerakan molekul semakin cepat (tumbukan antara molekul pereaksi meningkat). Temperatur mempengaruhi viskositas dan densitas, karena viskositas dan densitas merupakan dua parameter fisis penting yang mempengaruhi pemanfaatan biodiesel sebagai bahan bakar.

4. Kandungan air dan asam lemak bebas Terdapatnya air dalam trigliserida menyebabkan terjadinya reaksi saponifikasi yang
dapat menurunkan tingkat efisiensi katalis. Jika kandungan asam lemak bebasnya tinggi maka akan dibutuhkan banyak basa.

5. Kecepatan pengadukan

Setiap reaksi dipengaruhi oleh tumbukan antar molekul yang larut dalam reaksi dengan memperbesar kecepatan pengadukan maka jumlah tumbukan antar molekul zat pereaksi akan semakin besar sehingga kecepatan reaksi akan bertambah besar.

\section{Gelombang Mikro}

Gelombang mikro merupakan alternatif sumber energi yang dapat digunakan untuk mensuplai energi dalam reaksi kimia. Melalui pemanasan dielektrik, campuran reaksi dapat bercampur secara homogen tanpa kontak dengan dinding. Waktu yang diperlukan untuk reaksi secara keseluruhan dapat tereduksi secara signifikan (Santoso, 2008).

$$
\text { Radiasi gelombang mikro }
$$
merupakan radiasi non-ionisasi yang dapat 
memutuskan suatu ikatan sehingga menghasilkan energi yang dimanifestasikan dalam bentuk panas melalui interaksi antara zat atau medium. Energi tersebut dapat direfleksikan, ditransmisikan, atau diabsorbsikan (Varma, 1998).

Pemanasan dengan gelombang mikro mempunyai karakteristik yang berbeda dengan pemanasan konvensional, karena panas dibangkitkan secara internal akibat getaran molekul-molekul bahan yang ingin dipanaskan oleh gelombang mikro. Hal ini akan menghemat energi untuk pemanasan energi microwave yang diberikan atau dihantarkan secara langsung pada molekul-molekul yang bereaksi melalui reaksi kimia. Pindah panas menggunakan microwave lebih efektif daripada pemanasan secara konvensional dimana panas dipindahkan dari lingkungan (Lertsathapornsuk, dkk., 2004).

Proses pemanasan dengan microwave menggunakan waktu yang lebih singkat untuk memanaskan bahan baku tanpa pemanasan awal (Lertsathapornsuk, dkk., 2004). Selain itu penggunaan microwave menunjukkan reaksi yang lebih efisien, dengan lama reaksi dan proses pemisahan yang singkat, menurunkan jumlah produk samping, dan dapat menurunkan konsumsi energi (Hernando, dkk., 2007). Efisiensi dari transesterifikasi microwave berasal dari sifat dielektrik dari campuran polar dan komponen ion dari minyak, pelarut, dan katalis. Pemanasan yang cepat dan efisien pada radiasi microwave karena gelombang microwave berinteraksi dengan sampel pada tingkat molekular menghasilkan campuran intermolekul dan agitasi yang meningkatkan peluang dari sebuah molekul alkohol bertemu dengan sebuah molekul minyak (Terigar, 2009).

\section{METODOLOGI PENELITIAN}

Media yang digunakan berupa sebuah microwave yang dilengkapi dengan dua buah tangki umpan, satu buah tangki emulsifier lengkap dengan propeller, satu buah pompa portable, serta satu buah tangki separasi dengan 3 pasang elektroda.

\section{Tahap Persiapan}

Minyak jelantah diperoleh dari sebuah pabrik kemplang dan kerupuk yang ada di daerah Soak Kenten. Minyak jelantah yang didapat selanjutnya dilakukan uji kadar asam lemak bebas (ALB) dengan cara mengambil sebanyak 5 gr sampel minyak dan ditambahkan $50 \mathrm{ml}$ methanol. Selanjutnya, ditambahkan indikator pp dan dilakukan titrasi sampel dengan larutan $\mathrm{NaOH} \quad 0,1 \quad \mathrm{~N}$. Volume $\mathrm{NaOH}$ yang digunakan setelah sampel berubah warna merah muda dicatat dan dihitung nilai ALB dengan menggunakan rumus: (Sumber: Suroso, 2013)

$$
\% \mathrm{ALB}=\frac{\mathrm{V} \mathrm{NaOH} \times \mathrm{N} \mathrm{NaOH} \times \mathrm{BE} \text { Asam Lemak }}{\mathrm{m} \text { sampel }} \times 100
$$

Dengan,

$\mathrm{V}=$ volume $\mathrm{NaOH}(\mathrm{ml})$

$\mathrm{N}=$ normalitas larutan

$\mathrm{NaOH}(\mathrm{N})$

$\mathrm{m}=$ massa sampel $(\mathrm{gr})$

Bila nilai ALB dari minyak jelantah $>5 \%$ maka dilakukan proses adsorbsi dengan menggunakan adsorben berupa zeolit.

\section{Tahap Pembuatan Katalis Natrium Metoksida}

Katalis natrium metoksida dibuat dengan menimbang natrium hidroksida dan metanol yang dibutuhkan dan kemudian melarutkan natrium hidroksida ke dalam metanol yang telah ditimbang. Selanjutnya dilakukan pengadukan pada larutan hingga semua natrium hidroksida terlarut ke dalam metanol.

\section{Tahap Pembuatan Katalis Kalsium Oksida (CaO)}

Cangkang telur yang telah dikumpulkan dicuci dan direndam dengan aquadest selama 15-20 menit untuk menghilangkan pengotor-pengotor yang ada. Selanjutnya cangkang telur dikeringkan dalam oven pada temperatur $100^{\circ} \mathrm{C}$ selama 4 jam. Setelah dikeringkan, cangkang telur dihancurkan dengan lumpang. Cangkang telur yang kering ditimbang dan dikalsinasi 
memakai tungku (muffle furnace) pada temperatur $1000^{\circ} \mathrm{C}$ selama 2 jam.

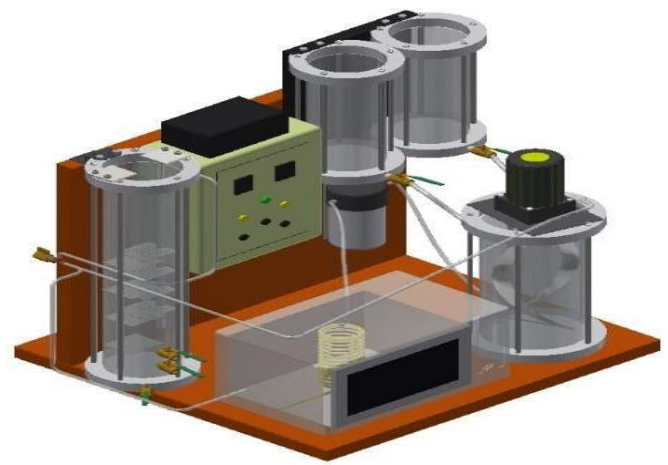

Gambar 1. Alat Produksi Biodiesel dengan Pemanfaatan Gelombang Mikro dan Tegangan Tinggi

\section{Tahap Pembuatan Biodiesel}

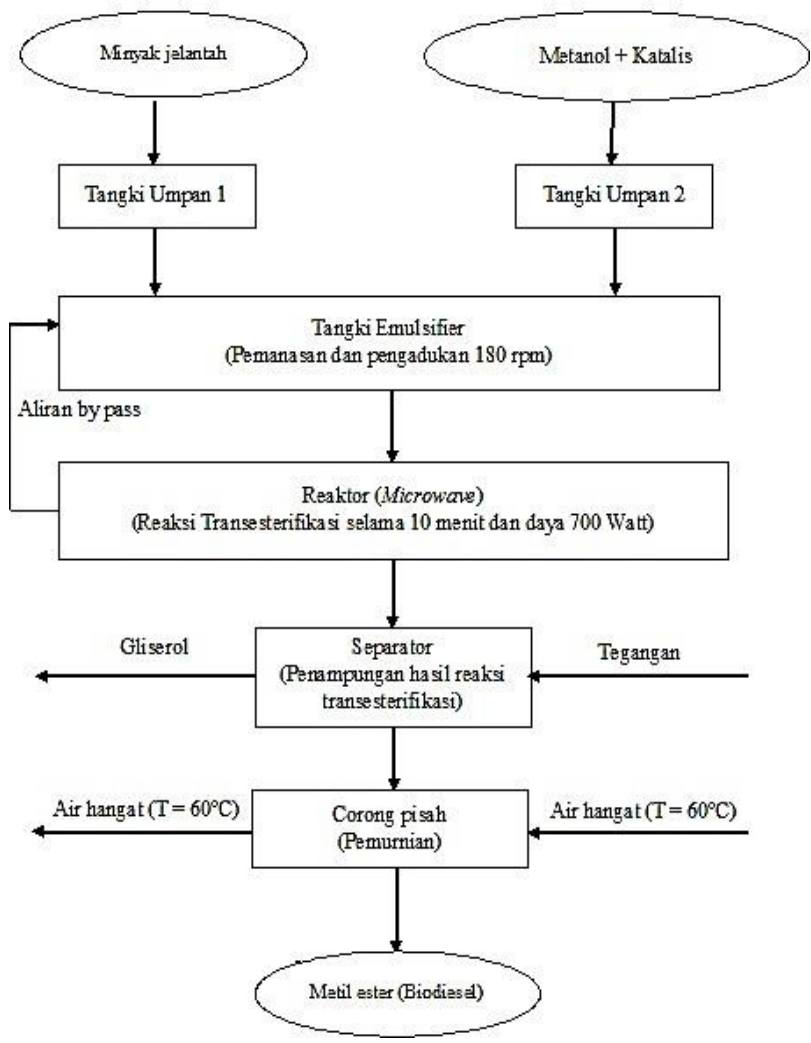

Gambar 2. Metodologi Pembuatan Biodiesel

\section{Tahap Pemurnian Biodiesel}

Pada tahapan ini air pada awalnya dipanaskan hingga temperaturnya mencapai $60^{\circ} \mathrm{C}$. Selanjutnya, biodiesel yang diperoleh dicampurkan dengan air yang telah dipanaskan ke dalam corong pisah dengan perbandingan volume 1:1. Air kemudian dipisahkan dari biodiesel dan diikuti dengan proses pemanasan biodiesel pada temperatur $40-48^{\circ} \mathrm{C}$. Biodiesel yang telah dipanaskan selanjutnya didinginkan hingga temperaturnya sama dengan temperatur lingkungan. Proses pemurnian dilakukan berulang hingga air pemurnian berwarna bening.

\section{HASIL DAN PEMBAHASAN}

\section{A. Pengaruh rasio minyak jelantah dan metanol terhadap persen rendemen biodiesel}

Rendemen merupakan suatu parameter yang penting untuk mengetahui nilai ekonomis dan efektivitas suatu proses produk atau bahan (Cucikodana, dkk., 2012). Persen rendemen biodiesel penting untuk diketahui agar dapat mengetahui seberapa ekonomis proses pembuatan biodiesel dengan metode yang diterapkan. Berdasarkan penelitian yang telah dilakukan menunjukkan bahwa persen rendemen biodiesel dipengaruhi oleh rasio massa minyak jelantah dan metanol. Grafik hubungan rasio massa minyak jelantah dan metanol terhadap persen rendemen biodiesel dapat dilihat pada Gambar 3.

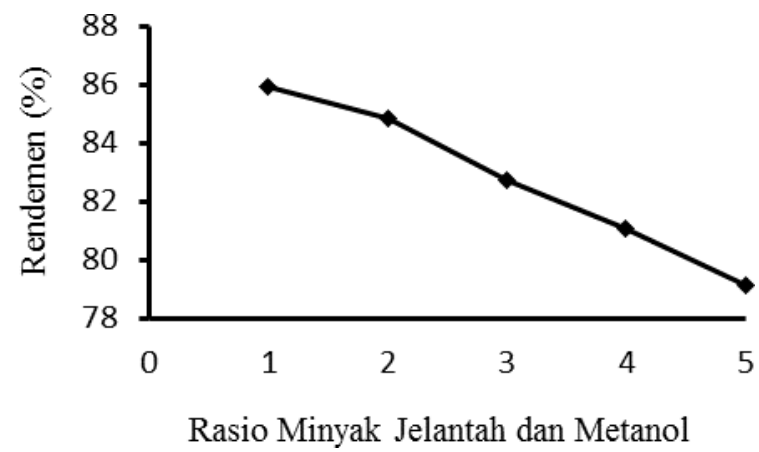

Gambar 3. Hubungan Rasio Minyak Jelantah dan Metanol Terhadap Rendemen Biodiesel

Pada Gambar 3 menunjukkan bahwa semakin kecil rasio massa minyak jelantah dan metanol maka persen rendemen yang dihasilkan akan semakin kecil. Hal ini dikarenakan jumlah metanol yang lebih besar pada perbandingan rasio yang kecil. Dengan menggunakan metanol yang 
berlebih maka reaksi dapat digeser ke kanan (ke arah pembentukan produk) untuk menghasilkan konversi yang maksimum. Pemakaian salah satu reaktan yang berlebih akan memperbesar kemungkinan tumbukan antara molekul zat yang bereaksi sehingga kecepatan reaksinya bertambah besar (Dharsono dan Oktari, 2013). Rendemen biodiesel tertinggi terdapat pada rasio masssa minyak jelantah dan metanol 5:1 yaitu sebesar 85,91\%.

\section{B. Pengaruh Jumlah Katalis $\mathrm{CaO}$ terhadap persen rendemen biodiesel}

Analisa persen rendemen dilakukan untuk mengetahui banyaknya produk biodiesel yang dihasilkan dengan bantuan katalis $\mathrm{CaO}$ dalam proses pembuatannya. Hasil analisa persen rendemen dapat dilihat pada Gambar 4.

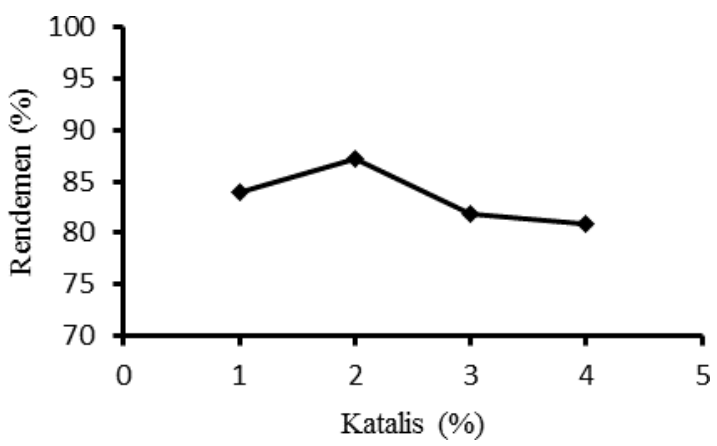

Gambar 4. Hubungan Jumlah Katalis Terhadap Rendemen Biodiesel

Dari Gambar 4 tersebut dapat dilihat bahwa jumlah katalis $2 \%$ dapat menghasilkan persen rendemen yang lebih tinggi dibandingkan jumlah katalis $4 \%$. Penggunaan katalis $2 \%$ mengakibatkan jumlah molekul yang saling mengalami tumbukan semakin banyak sehingga kecepatan reaksi transesterifikasi yang terjadi juga semakin meningkat (Indah, dkk., 2011). Namun, penggunaan katalis yang melebihi $2 \%$ mengalami penurunan diakibatkan oleh banyaknya endapan katalis yang mempengaruhi reaksi transesterifikasi yang terjadi. Endapan ini akan mempengaruhi kesetimbangan reaksi sehingga reaksi akan menghasilkan produk samping yang lebih banyak (Nurhayati, dkk., 2014)

\section{c. Pengaruh temperatur reaksi terhadap persen rendemen biodiesel}

Temperatur reaksi akan berpengaruh terhadap reaksi transesterifikasi yang terjadi. Temperatur reaksi yang digunakan pada penelitian ini adalah $35,40,45,50,55$, dan $60^{\circ} \mathrm{C}$. Grafik hubungan temperatur reaksi terhadap persen rendemen biodiesel dapat dilihat pada Gambar 5.

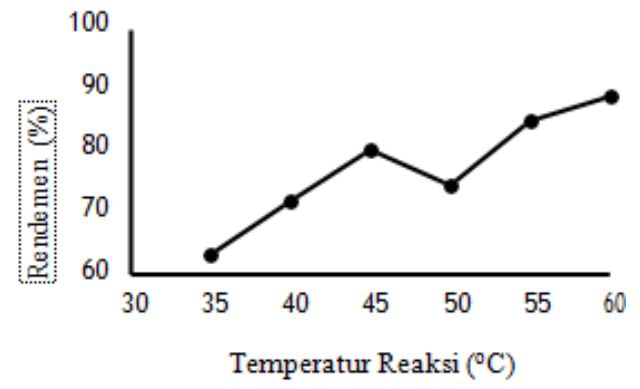

Gambar 5. Hubungan Temperatur Reaksi Terhadap Persen Rendemen Biodiesel

Berdasarkan Gambar 5 diatas, terjadi peningkatan persen rendemen biodiesel seiring dengan peningkatan temperatur reaksi. Persen rendemen yang tinggi ini dikarenakan adanya gerakan molekul pereaksi yang semakin cepat. Hal ini sesuai dengan Wahyuni, dkk. (2015), yaitu semakin tinggi temperatur menyebabkan gerakan molekul semakin cepat atau energi kinetik yang dimiliki molekul-molekul pereaksi semakin besar sehingga tumbukan antara molekul pereaksi juga meningkat. Kenaikan temperatur akan menaikkan laju reaksi yang terjadi akibat dari adanya kenaikan energi kinetik sistem (Fauzi, 2013). Persen rendemen yang rendah pada temperatur $50^{\circ} \mathrm{C}$ dimungkinkan karena reaksi transesterifikasi yang terjadi tidak sempurna sehingga menghasilkan konversi yang rendah akibat dari pergeseran reaksi kearah reaksi saponifikasi yang lebih banyak menghasilkan sabun daripada metil ester. 


\section{Pengaruh tegangan terhadap persen rendemen biodiesel}

Penggunaan tegangan tinggi pada proses separasi akan mempengaruhi lama waktu proses pemisahan yang terjadi. Pada penelitian ini digunakan tegangan $6,7,8,9$, dan $10 \mathrm{kV}$. Berdasarkan penelitian yang telah dilakukan menunjukkan bahwa persen rendemen biodiesel dipengaruhi oleh tegangan yang digunakan. Adapun grafik hubungan tegangan terhadap persen rendemen biodiesel dapat dilihat pada Gambar 6.

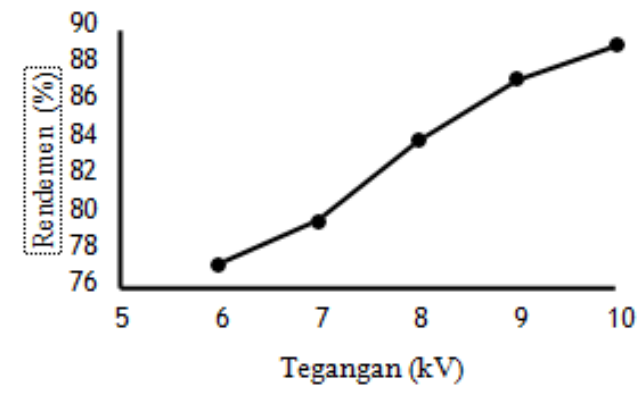

Gambar 6. Hubungan Tegangan Terhadap Rendemen Biodiesel

Pada Gambar 6 dapat dilihat bahwa pada tegangan $6 \mathrm{kV}$ menghasilkan rendemen biodiesel sebanyak $77,28 \%$ sedangkan pada tegangan $10 \mathrm{kV}$ menghasilkan rendemen biodiesel sebesar $89,12 \%$. Hal ini menunjukan hubungan antara tegangan terhadap rendemen biodiesel. Semakin besar tegangan maka rendemen biodiesel yang dihasilkan akan semakin besar. Menurut Yudhistira dan Isitiadi (2013) bahwa tegangan tinggi berfungsi untuk mempercepat waktu pemisahan atau untuk memperoleh hasil rendemen biodiesel yang cukup banyak. Hal ini sesuai menurut teori elektroforesis yaitu teknik pemisahan komponen atau molekul bermuatan berdasarkan perbedaan tingkat migrasinya dalam sebuah medan listrik. Medan listrik dialirkan pada suatu medium yang mengandung sampel yang akan dipisahkan. Teknik ini dapat digunakan dengan memanfaatkan muatan listrik yang ada pada makromolekul, misalnya DNA yang bermuatan negatif. Jika molekul yang bermuatan negatif dilewatkan melalui suatu medium, kemudian dialiri arus listrik dari suatu kutub ke kutub yang berlawanan muatannya maka molekul tersebut akan bergerak dari kutub negatif ke kutub positif.

\section{E. Pengaruh jarak elektroda terhadap persen rendemen biodiesel}

Jarak elektroda akan mempengaruhi proses pengaliran aliran listrik pada campuran bahan yang akan dipisahkan. Antara kedua elektroda memiliki jarak optimum yang akan mempengaruhi elektron yang berpindah (Putra dan Agusta, 2011). Semakin jauh jarak antar elektroda maka jarak tempuh elektron akan semakin panjang sehingga akan menambah waktu proses yang tengah berlangsung (Putra dan Agusta, 2011). Grafik hubungan jarak elektroda terhadap persen rendemen biodiesel dapat dilihat pada Gambar 7.

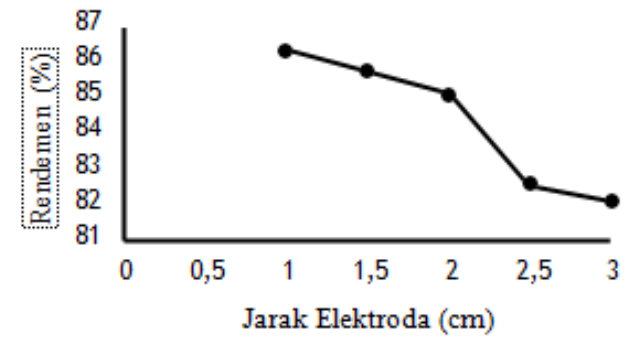

Gambar 7. Hubungan Jarak Elektroda Terhadap Rendemen Biodiesel

Pada Gambar 7 dapat dilihat bahwa rendemen biodiesel tertinggi dihasilkan pada jarak elektroda $1 \mathrm{~cm}$, yaitu $86,34 \%$. Semakin dekat jarak elektroda maka rendemen biodiesel yang dihasilkan akan semakin besar. Menurut Abbaszadeh, dkk. (2014), jarak elektroda mempengaruhi waktu pemisahan dan hasil rendemen biodiesel yang cukup banyak. Hal ini sesuai dengan teori elektroforesis bahwa teknik pemisahan komponen atau molekul bermuatan berdasarkan perbedaan tingkat migrasinya dalam sebuah medan listrik. 
Medan listrik dialirkan pada suatu medium yang mengandung sampel yang akan dipisahkan. Teknik ini dapat digunakan dengan memanfaatkan muatan listrik yang ada pada makromolekul, misalnya DNA yang bermuatan negatif. Jika molekul yang bermuatan negatif dilewatkan melalui suatu medium, kemudian dialiri arus listrik dari suatu kutub ke kutub yang berlawanan muatannya maka molekul tersebut akan bergerak dari kutub negatif ke kutub positif.

\section{KESIMPULAN DAN SARAN \\ 5.1 Kesimpulan}

Dari hasil penelitian pembuatan biodiesel dengan pemanfaatan gelombang mikro dan tegangan tinggi, dapat disimpulkan bahwa:

1. Rasio minyak jelantah dan metanol mempengaruhi besarnya rendemen yang didapatkan, yaitu rendemen tertinggi yang didapatkan dari pembuatan biodiesel dengan menggunakan gelombang mikro berdasarkan variasi rasio massa minyak jelantah dan methanol adalah pada rasio 6:1 dengan rendemen biodiesel sebesar $84,84 \%$.

2. Penggunaan jumlah katalis juga mempengaruhi besarnya rendemen yang didapatkan, yaitu rendemen tertinggi dari pembuatan biodiesel dengan katalis $\mathrm{CaO}$ terjadi pada jumlah katalis sebesar $2 \%$, yaitu $87,12 \%$.

3. Hubungan antara temperatur reaksi dengan rendemen biodiesel adalah semakin tinggi temperatur reaksi yang digunakan maka rendemen biodiesel yang didapatkan akan semakin tinggi dimana rendemen tertinggi dapat dicapai menggunakan temperatur reaksi $60^{\circ} \mathrm{C}$ dengan rendemen sebesar $88,88 \%$.

4. Variasi tegangan yang dapat menghasilkan biodiesel dengan rendemen tertinggi adalah $10 \mathrm{kV}$ sebesar $89,12 \%$

5. Jarak dan jenis elektroda berpengaruh dalam pemisahan gliserol dengan biodiesel, yaitu semakin jauh jarak elektroda maka semakin sedikit jumlah gliserol yang dapat dipisahkan dimana rendemen tertinggi didapatkan dengan penggunaan jarak elektroda $1 \mathrm{~cm}$ yaitu $86,34 \%$.

\section{DAFTAR PUSTAKA}

Abbaszadeh, Ahmad, B. Ghobadian, dan G. Najafi. 2014. Electrostatic Coagulation for Separation of Crude Glycerin from Biodiesel. Iran: Tarbiat Modares University.

Cucikodana, Yunita, Agus Supriadi, dan Budi Purwanto. 2012. Pengaruh Perbedaan Suhu Perebusan dan Konsentrasi $\mathrm{NaOH}$ Terhadap Kualitas Bubuk Tulang Ikan Gabus (Channa striata). Palembang: Universitas Sriwijaya.

Dharsono, W. dan Oktari, Y.S. 2013. Proses Pembuatan Biodiesel dari Dedak dan Metanol dengan Esterifikasi In Situ. Jurnal Teknologi Kimia dan Industri, 33- 39.

Fauzi, Irwan. 2013. Pengaruh Nisbah Metanol, Temperatur, dan Waktu Reaksi pada Rendemen Biodiesel dalam Transesterifikasi In Situ Biji Bintaro. Bogor: Departemen Kimia, Fakultas Matematika dan Ilmu Pengetahuan Alam Institut Pertanian Bogor.

Indah S., Tuti, M. Said, Adhitya S.W., dan Ani K. Sari. 2011. Katalis Basa Heterogen Campuran $\mathrm{CaO}$ dan $\mathrm{SrO}$ pada Reaksi Transesterifikasi Minyak Kelapa Sawit. Palembang: Prosiding Seminar Nasional AVoER ke-3.

Hernando, J. Leton, P., Matia, M.P., Novella, J.L., dan Alvarez-Builla, J. 2007. Biodiesel and FAME Synthesis Assisted 
P-ISSN: 2089-5925 E-ISSN: 2621-9328

tintrant

Jurnal Teknik Patra Akademika

PA

A KaAemiKa

Volume 09 No 01 Juli 2018 